\title{
ANALISIS CYBERBULLYING DALAM BERBAGAI PERSPEKTIF TEORI VIKTIMOLOGI
}

\author{
Dewi Bunga \\ bunga8287@gmail.com
}

\begin{abstract}
Abstrak
Pengkajian mengenai isu cyberbullying bukanlah hal yang mudah. Berbagai pendekatan perlu dilakukan untuk menganalisis isu ini. Pembahasan mengenai cyberbullying dilakukan dengan meminjam teori viktimologi kritis sebagaimana yang dipaparkan dalam bukuVictimology Victimisation and Victims' Rightskarya Lorraine Wolhuter, Neil Olleydan David Denham. Teori viktimologi kritis cukup relevan dalam menganalisis mengenai korban cyberbullying, yakni dalam taksonomi korban anak. Tulisan dalam buku Victimology Sixth Editionkarya William G. Doerner Steven P. Lab juga sangat berguna dalam menganalisis masalah kekerasan dalam cyberbullying. Dalam kajian mengenai Intimate Partner Violence, William G. Doerner Steven P. Lab menguraikan mengenai lingkaran kekerasan yang berasal dari lingkungan keluarga. Kekerasan yang terjadi dalam hubungan antara pasangan ini akan berdampak terhadap perlakuan yang salah pada anak sebagaimana yang dibahas dalam chapter 10. Pelaku cyberbullying biasanya berada di dalam lingkungan kekerasan, yang mengekspresikan kemarahan dan kebenciannya dalam perkataan dan perbuatan baik di dunia nyata maupun di dunia maya. William G. Doerner Steven P. Lab. juga membahas mengenai bullying yang terjadi pada anak-anak di usia sekolah serta respon lingkungan sekolah terhadap kekerasan tersebut. Tulisan-tulisan tersebut akan menjadi bahan dalam kebijakan hukum pidana terhadap cyberbullying.
\end{abstract}

Kata kunci: Cyberbullying, viktimologi kritis, anak, kekerasan.

\section{Pendahuluan}

Pemahaman konseptual hukum mengenai cyberbullying sampai saat ini belum sampai pada tingkat kemapaman. Hal tersebut menjadi sesuatu yang wajar mengingat cyberbullying sendiri bukan merupakan istilah hukum. Pertanggungjawaban pidana terhadap pelaku cyberbullying hingga kini belum memiliki batas yang tegas, sebab tidak semua perilaku antisosial ini menjadi masalah hukum, apalagi jika pelakunya adalah anak-anak. Mengenai hal tersebut, dalam Cyberbullying Research Center, Sameer Hinduja dan Justin W. Patchin ${ }^{1}$ mengatakan sebagai berikut:

Like traditional bullying, cyberbullying behaviors vary significantly along a continuum ranging from isolated, trivial, and innocuous incidents to serious and enduring torment. The problem is that few can agree on the precise point at which a particular behavior crosses the threshold and becomes something that should be addressed in a courtroom.
Seperti halnya bullying tradisional, perilaku cyberbullying sangat bervariasi dari rangkaian panjang mulai dari terisolasi, sepele, tidak berbahaya sampai serius dan siksaan yang cukup lama. Permasalahannya adalah hanya sedikit yang dapat menyetujui titik yang tepat dimana perilaku tertentu telah melewat batas dan harus diselesaikan di ruang sidang (translasi oleh peneliti).

Cyberbullying sebagai suatu perilaku antisosial, dapat ditinjau dari beberapa aspek seperti kriminologi, viktimologi, psikologi dan psikiatri. Dalam membedah perilaku cyberbullying itu sendiri maka dilakukan dengan pelbagai pendekatan. Peneliti setidaknya melakukan kajian literatur terhadap dua buku yang relevan yakni Victimology Victimisation and Victims' Rightskarya Lorraine Wolhuter, Neil Olley dan David Denham dan Victimology Sixth Editionkarya William G. Doerner Steven P. Lab. 
Lorraine Wolhuter, Neil Olley dan David Denham dalam Chapter 2 membahas mengenai Theories of Victimology(teori-teori viktimologi). Teori viktimologi tersebut sangat berguna untuk menganalisis cyberbullying dalam perspektif korban. Dalam bab tersebut, penulis mengemukakan klasifikasi yang lebih kompleks dari kaum positivis, konservatif(kadang-kadang disebut realisme kanan), Marxis dan realisme kiri (mewakili perspektif yang berbeda dalam kriminologi radikal), feminisme dan viktimologi kritis. Teori viktimologi kritis adalah teori yang paling relevan untuk menganalisis cyberbullying, khususnya dalam membahas mengenai hak-hak korban.

Perilaku cyberbullying terhadap anak dapat dilakukan oleh siapa saja, baik orang dewasa maupun anak-anak. Keterlibatan anak sebagai pelaku cyberbullying memang sering terjadi pada masa kanak-kanak. Anak sebagai pelaku sesungguhnya merupakan korban dari lingkungan sosial terdekatnya, yaitu keluarga. Ybarra dan Mitchell ${ }^{2}$ telah melakukan langkah awal dalam membuat profil dari cyberbullying, yakni:

Besides, Cyber Bullies tend to have poor relationships with their caregivers and are twice as likely as non-Cyber Bullies to report on the following:

a. A poor emotional bond with caregivers

b. Wrong methods of disciplining

c. Infrequent caregiver monitoring

d. Often intensive Internet users

e. Quickly switch screens or close programs when others walk by

$f$. Frequent use the computer in the wee hours of the night

g. Get unusually upset if he/she cannot use the computer

h. Laugh excessively while using the computer

$i$. Avoid discussions about what he or she is doing on the computer

$j$. Use multiple online accounts or an account that is not his or her own

Selain itu, pelaku cyberbullying cenderung memiliki hubungan yang buruk dengan pengasuh mereka dan kemungkinan dua kali lebih banyak daripada yang bukan pelaku cyberbullying untuk melaporkan hal berikut:

a. Sebuah ikatan emosional yang buruk dengan pengasuh

b. Kesalahan dalam metode mendisiplinkan

c. Pemantauan pengasuh yang jarang terjadi

d. Seringkali pengguna internet secara intensif

e. Cepat beralih layar atau menutup program saat orang lain lewat

f. Sering menggunakan komputer di larut malam

g. Gangguan luar biasa jika dia tidak dapat menggunakan komputer

h. Tertawa berlebihan saat menggunakan komputer

i. Menghindari diskusi tentang apa yang sedang dia lakukan di komputer

j. Menggunakan beberapa akun online atau akun yang bukan miliknya sendiri (translasi oleh peneliti).

Keluarga merupakan lingkungan sosial uang terdekat untuk membesarkan, mendewasakan, dan menjadi tempat pendidikan pertama bagi anak. ${ }^{3}$ Dengan melihat fakta tersebut, peneliti melakukan tinjauan buku yang membahas mengenai Intimate Partner Violenceyang dibahas pada chapter 9 Victimology Sixth Editionkarya William G. Doerner Steven P. Lab.Intimate partner violencemerupakan suatu kajian yang cukup banyak dibahas dalam dunia psikiatri. Daniel Dicola danElizabeth Spaar ${ }^{4}$ mengatakan "Intimate partner violence (IPV) is a prevalent worldwide health problem, affecting women more commonly than men. It can include physical, emotional, sexual, and financial abuse, as well as control over contraception or pregnancy and medical care."Kekerasan terhadap pasangan intim (intimacy violence violence / IPV) adalah masalah kesehatan umum di seluruh dunia, yang lebih sering mempengaruhi perempuan daripada laki-laki. Ini bisa termasuk pelecehan fisik, emosional, seksual, dan finansial, serta kontrol terhadap kontrasepsi atau kehamilan dan perawatan medis (translasi oleh peneliti). 
Kajian terhadap Intimate partner violencedapat menjadi titik awal dari dan akar masalah dari perlakuan yang salah terhadap anak sebagaimana yang dibahas dalam Chapter 10 Child Maltreatmentpada Victimology Sixth Editionkarya William G. Doerner Steven P. Lab. Perlakuan yang salah terhadap anak akan membuat anak tidak terlindungi secara optimal, sehingga anak bertendensi menjadi pelaku maupun korban dari cyberbullying. Bab ini mengulas mengenai kajian terhadap anak yang menjadi korban dari perlakuan yang salah di dalam keluarganya. Beberapa kasus kekerasan terhadap anak seperti penganiayaan, kekerasan seksual, penculikan, dan sebagainya merupakan bentukbentuk kekejaman terhadap anak yang memerlukan perhatian khusus.

Bagian lain yang dikaji adalah tulisan William G. Doerner Steven P. Labdalam Chapter 12 yakni Victimization at Work and School. Dalam bagian ini, William G. Doerner Steven P. Labmenguraikan mengenai viktimisasi yang terjadi di tempat kerja dan sekolah. Penelitian dilakukan dengan menunjukkan pola kekerasan, cara mencegah, tanggapan korban, respon sekolah dan tempat kerja. Analisis juga menjabarkan bentuk kekerasan yang dikaji secara spesifik yaitu masalah bullying dan kekerasan seksual. Dalam mengkaji buku ini, peneliti ingin menggali isu mengenai bullying yang terjadi di dunia nyata dan membandingkannya dengan yang terjadi di dunia maya.

\section{Kajian terhadap Chapter 2 Theories of Victimology}

Pada Chapter 2 buku karya Lorraine Wolhuter, Neil Olley dan David Denham ini dibahas mengenai Theories of victimologyatau teori viktimologi. Penulis menghubungkan teoriteori viktimologi dengan teori-teori kriminologi yang memiliki sejarah lebih panjang dibandingkan dengan pembahasan mengenai korban kejahatan. Studi tentang korban didorong oleh perhatian politik tentang korban, gerakan perlindungan korban, perkembangan sosial dan respon peradilan pidana akan kebutuhan korban. Dalam studi tentang korban tersebut ditinjau beberapa aspek yang meliputi teori viktimologi, kebutuhan korban, dampak viktimisasi, ketakutan terhadap kejahatan dan survei tentang korban. Dalam menguraikan mengenai teori viktimologi, penulis mengemukakan beberapa para ahli dalam pembagian aliran viktimologi.

Ulasan dilakukan secara tajam dan terperinci. Penulis juga mengemukakan berbagai pandangan yang mengkritik pandangan-pandangan dalam setiap teori tersebut. Kelemahan-kelemahan dalam suatu teori sesungguhnya merupakan hal yang wajar mengingat studi mengenai korban kejahatan merupakan studi yang sangat kompleks, yang tidak mungkin dirangkum dalam satu penelitian yang berlaku bagi semua kejahatan. Salah satu aliran viktimologi yang menarik dan dibahas pada buku ini adalah teori viktimologi kritis.

Teori viktimologi kritis merupakan hasil pemikiran dari Mawby dan Walklate yang sebelumnya telah mengkritik kaum positivis karena menjadikan korban untuk mencari keteraturan atau pola yang memicu viktimisasi. Mawby dan Walklate juga menyoroti kelemahan radikalisme radikal. Mereka berpendapat bahwa terlepas dari kenyataan bahwa penganiayaan radikal, dalam penekanannya pada peran negara dalam menghasilkan definisi kriminalitas dan kekebalan. Dalam usaha untuk mengatasi kelemahan positivis dan radikal, Mawby dan Walklate mengembangkan sebuah viktimologi kritis yang berkaitan dengan mendokumentasikan realitas hidup korban serta bagaimana struktur sosial membentuk realitas hidup ini. Subyektivitas manusia sangat penting bagi penggambaran kenyataan hidup korban yang akurat.

Dalam Sage Knowledge disebutkan "The sense in which Walklate $(1989,1990)$ has attempted to develop an understanding of critical victimology has been concerned in the first instance to establish an understanding of the relationship between epistemology, methodology and the political agenda." (Dalam pandangan Walklate, telah berusaha untuk mengembangkan pemahaman tentang viktimologi 
kritis sebagaimana yang telah dikemukakan pada awalnya untuk membangun pemahaman tentang hubungan antara epistemologi, metodologi dan agenda politik). Lorraine Wolhuter, Neil Olley dan David Denham memang tidak secara tegas mengkaji mengenai kajian filsafat dalam menganalisis teori viktimologi kritis.

Mawby dan Walklate mengatakan bahwa teori viktimologi kritis tidak hanya terfokus pada kenyataan hidup korban. Mawby dan Walklate berpendapat bahwa analisis 'hubungan rekursif antara lembaga dan struktur' diperlukan untuk memahami bagaimana proses historis, budaya dan sosio-ekonomi, dan juga kekuatan negara, ' mendukung tindakan individual tertentu pada saatsaat tertentu. Lebih lanjut dikatakan bahwa korban memiliki potensi 'untuk mempertahankan dan mengubah kondisi di mana mereka bertindak' Salah satu cara sentral untuk mencapai perubahan tersebut adalah melalui advokasi gerakan korban untuk pengakuan hak korban. ${ }^{6}$

Pembahasan mengenai cyberbullying dalam perspektif viktimologi merupakan diskursus cyberbullying dengan pendekatan dalam perspektif korban. Teori viktimologi kritis cukup relevan untuk digunakan dalam menganalisis mengenai cyberbullying yakni pada isu kunci sebagai berikut:

a. Viktimologi kritis mengindentifikasi mengenai hak-hak korban. Pandangan ini sangat penting mengingat cyberbullying sendiri belum dianggap sebagai suatu permasalahan, melainkan dianggap tindakan wajar di masa kanak-kanak. Dengan pandangan demikian, maka sudah tentu hak-hak dari korban cyberbullying belum banyak disadari, meskipun dampak perilaku ini sangat nyata.

b. Pemahaman mengenai proses historis, budaya dan sosio-ekonomi sangat perlu dilakukan untuk membedah cyberbullying secara konseptual. Pemahaman ini dapat mengkaji faktor-faktor penyebab cyberbullying.

c. Kekuatan negara dalam perlindungan korban. Elemen ini dapat menjadi kajian dalam menelaah perlindungan negara terhadap korban, baik melalui kebijakan penal maupun kebijakan non penal.
Teori viktimologi kritis memang sangat membantu dalam menelaah mengenai cyberbullying terlepas dari pandangan bahwa korban merupakan konsep yang netral dan sama sekali tidak mengkaji mengenai peranan korban dalam suatu kejahatan. Secara faktual, terjadinya cyberbullying tidak dapat dilepaskan dari faktorfaktor yang diciptakan oleh korban sendiri sehingga dirinya berpotensi sebagai korban, misalnya ketika anak mengunggah foto mesra dengan pasangannya. Foto tersebut dapat diteruskan oleh para netizen dan membuat anak tersebut menjadi korban cyberbullying.

Kelemahan-kelemahan pada teori viktimologi kritis dalam mengkaji mengenai cyberbullying tidak dapat dilepaskan dari fenomena cyberbullying itu sendiri. Dorothy Wunmi Grigg7mengatakan "It is acknowledged that the field of cyberbullying is a relatively new one and, as such, research within this area has to propose a broader concept that embraces negative behaviours of internet and mobile phone users without current cyberbullying definitional and conceptual issues." (Diakui bahwa bidang penindakan maya adalah hal yang relatif baru dan, oleh karena itu, penelitian di bidang ini harus mengajukan konsep yang lebih luas yang mencakup perilaku negatif pengguna internet dan pengguna ponsel tanpa masalah definisi dan konseptual tentang cyberbullying saat initranslasi oleh peneliti).

\section{Kajian terhadap Chapter 9 Intimate Partner Violence}

Pada bab 9 tentang kekerasan dalam hubungan dengan pasangan ini, William G. Doerner Steven P. Labmengemukakan satu hal yang sangat menarik, yaitu "Orang yang saling mencintai dapat melakukan kekerasan secara intens." Keberlanjutan dalam tindak kekerasan tersebut disebabkan karena pilihan dari korban itu sendiri. Dalam bab 9 penulis mengupas mengenai kekerasan yang terjadi dalam hubungan dengan pasangan. Walaupun dalam beberapa bagian penulis menguraikan hubungan tersebut mencakup hubungan pacaran dan hubungan sesama jenis, namun dalam bagian lain, penulis lebih banyak 
menekankan istilah intimate patner pada hubungan suami dengan istri. Kekerasan yang terjadi dalam hubungan antara orang tua dan anak akan melahirkan kondisi ketertekanan yang dapat membentuk taksonomi pelaku anak dalam cyberbullying.

Ketertekanan yang berimplikasi pada kekerasan ini banyak dibahas dalam General Strain Theory sebagaimana yang dikemukakan Agnew.Larry J. Siegel menganalisis pemikiran Agnew dan selanjutnya menuliskan "Agnew suggests that criminality is the direct result of negative affective states-the anger and frustration that emerge in the wake of destructive social relationships. He finds that negative affective states are produced by a variety of sources of strain." 8 (Agnew mengemukakan bahwa kriminalitas adalah akibat langsung dari keadaan afektif negatif - kemarahan dan frustrasi yang muncul setelah hubungan sosial yang merusak. Dia menemukan bahwa keadaan afektif negatif dihasilkan oleh berbagai sumber ketegangan-translasi oleh peneliti).

Kekerasan yang terjadi dalam hubungan dengan pasangan tidak dapat dilepaskan dari dominasi laki-laki terhadap perempuan. Dalam Hukum Romawi, perempuan dipandang sebagai milik laki-laki, baik oleh ayahnya atau oleh suaminya setelah wanita tersebut melangsungkan perkawinan. Hal ini kemudian dianggap sebagai sebuah kebiasaan yang diperkuat oleh bagianbagian alkitabiah, Kristen, hukum umum Inggris, dan adat istiadat koloni Amerika (Dobash \& Dobash, 1977-78, 1979; Edwards, 1989; Pleck, 1989). Segala tindakan yang dilakukan perempuan menjadi tanggung jawab bagi laki-laki sehingga perempuan berada dan tunduk pada kontrol laki-laki yang memegang kekuatan hidup dan mati mereka.

Dominasi laki-laki terhadap perempuan ini disadari oleh kaum feminis. Teori feminisme dilatarbelakangi dari pemikiran mengenai mayoritas tatanan hukum dibangun atas pandangan dunia yang bias dimana hukum dikonstruksikan dalam logika laki-laki. Perempuan dikonstruksikan berada pada posisi yang lebih rendah daripada laki- laki. Pandangan inilah yang mendapatkan perlawanan dari penganut teori Legal Feminisme. Perlawanan ditunjukkan dengan Gramsci yakni pentingkatan kesadaran ideologi. Penggunaan jalur ini penting, oleh karena perempuan sudah terpenjara dalam ideologi keutamaan laki-laki. Mereka berada dalam kesadaran palsu (false consciousness) tentang realitas dunia (yang mengunggulkan laki-laki), seolah realitas itu memang normal adanya, alamiah dan tidak dapat dirubah. Selama kaum hawa masih terkurung dalam kesadaran palsu dan belum memiliki kesadaran terhadap dunia tempat mereka berada, maka peminggiran dan diskriminasi gender akan terus terpelihara. ${ }^{9}$

Sebenarnya, banyak budaya Barat melarang hukuman resmi terhadap wanita dalam kode hukum mereka. Gerakan hukum di negara ini untuk membatasi pemukulan istri dapat dibagi menjadi tiga tahap. Adapun periodisasi tersebut dapat dirinci sebagai berikut:

1) Periode pertama terjadi pada pertengahan 1600-an, ketika orang-orang Puritan di Massachusetts memberlakukan undang-undang melawan pemukulan terhadap istri dan kekerasan dalam rumah tangga (Pleck, 1989). Walaupun undang-undang ini jarang diberlakukan. Kelalaian ini sebagian besar disebabkan oleh keyakinan kuat akan privasi keluarga dan penerimaan kekuatan fisik oleh suami sebagai bentuk disiplin yang sah.

2) Periode kedua muncul pada akhir 1800 -an, ketika negara-negara mulai mengeluarkan undang-undang yang membatasi kekerasan dalam rumah tangga. Kekhawatiran akan imigrasi, meningkatnya kejahatan, penggunaan alkohol, dan faktor-faktor lain mendorong berlalunya undang-undang yang membatasi konflik keluarga dan membiarkan intervensi dari luar (Pleck, 1989). Hukum dan hukuman ini jarang ditegakkan (Pleck, 1989).

3) Periode ketiga dilakukan pada tahun 1960-an yang berawal dari keresahan sosial umum dan tuntutan untuk kesetaraan setelah berbagai kasus pemerkosaan, perlakuan yang salah terhadap pasangan intim, dan kekerasan dalam 
rumah tangga. Periode ini dipelopori oleh para dokter dan pekerja sosial yang berhasil mengangkat isu ini menjadi isu publik. Pada masa ini, pelibatan polisi dalam penyelesaian kasus kekerasan semakin besar.

Perubahan besar dalam penyelesaian kasus kekerasan terhadap pasangan terjadi sejak publikasi ilmiah pada tahun 1984 dari the Minneapolis Experiment, yang mengevaluasi keefektifan penangkapan terhadap suami yang melakukan kekerasan. Penelitian ini menghasilkan banyak perubahan kebijakan. Setidaknya ada lima bentuk utama dari kekerasan terhadap pasangan yakni penganiayaan fisik, pelecehan seksual, pelecehan emosional, penganiayaan ekonomi, dan penganiayaan psikologis. Kekerasan dalam rumah tangga dapat berupa tindakan fisik, seksual, emosional, ekonomi, atau psikologis atau ancaman tindakan yang mempengaruhi orang lain. Tindakan ini termasuk perilaku yang mengintimidasi, memanipulasi, mempermalukan, mengisolasi, menakut-nakuti, meneror, memaksa, mengancam, menyalahkan, menyakiti, melukai, atau melukai seseorang.

a) Kekerasan fisik: Menekan, menampar, mendorong, menyambar, mencubit, menggigit, menarik rambut, dll. Pelecehan fisik juga termasuk menolak perawatan medis pasangan atau memaksa penggunaan alkohol dan / atau narkoba.

b) Kekerasan seksual: Memaksa atau mencoba untuk memaksa setiap kontak atau perilaku seksual tanpa persetujuan. Pelecehan seksual mencakup, namun tentu saja tidak terbatas pada perkosaan dalam perkawinan, serangan terhadap bagian seksual tubuh, memaksa seks setelah melakukan kekerasan fisik, atau memperlakukannya dengan cara yang merendahkan seksual.

c) Kekerasan emosional: Merusak rasa harga diri dan / atau harga diri seseorang. Tindakan ini mungkin termasuk, namun tidak terbatas pada kritik konstan, mengurangi kemampuan seseorang, menelepon nama, atau merusak hubungan seseorang dengan anak-anaknya. d) Kekerasan ekonomi: Membuat atau mencoba membuat individu bergantung secara finansial dengan mempertahankan kontrol penuh atas sumber keuangan, menahan akses seseorang terhadap uang, atau melarang kehadiran seseorang di sekolah atau pekerjaan.

e) Kekerasan Psikologis: Menyebabkan ketakutan karena intimidasi; mengancam kerusakan fisik pada diri, pasangan, anak-anak, atau keluarga pasangan atau teman; penghancuran hewan peliharaan dan harta benda; dan mengisolasi paksa dari keluarga, teman, atau sekolah dan / atau pekerjaan.

Kekerasan yang terjadi dalam hubungan dengan pasangan dilakukan berulang-ulang. Akibat dimensi kekerasan yang terjadi sangat mempengaruhi kondisi korban. Menurut Galtung, ada enam dimensi penting dalam kekerasan yaitu: a. Kekerasan fisik dan psikologi. Kekerasan bukan hanya melukai fisik seseorang namun juga berdampak pada jiwa seseorang. Kebohongan, indoktrinasi, ancaman dan tekanan adalah contoh kekerasan psikologi karena dimaksudkan untuk mengurangi kemampuan mental dan otak.

b. Pengaruh positif dan negatif. Kekerasan terjadi tidak hanya bila ia dihukum jika ia bersalah, namun juga dengan memberi imbalan ketika ia tidak bersalah. Sistem imbalan sebenarnya mengandung pengendalian, tidak bebas, kurang terbuka dan cenderung manipulatif, meskipun membawa kenikmatan. Ia mau menekankan bahwa kesadaran untuk memahami kekerasan yang luas itu penting.

c. Ada objek atau tidak. Objek yang disakiti umumnya adalah manusia secara langsung.

d. Ada subjek atau tidak. Jika kekerasan memiliki subjek atau pelaku, maka ia bersifat langsung atau personal, namun jika tidak ada pelakunya, maka kekerasan tersebut tergolong pada kekerasan struktural atau tidak langsung.

e. Di sengaja atau tidak. Perbedaan ini penting ketika orang harus mengambil keputusan mengenai kesalahan. Sering konsep tentang kesalahan ditangkap sebagai suatu perilaku yang sengaja, kesalahan yang walau tidak 
disengaja tetap merupakan suatu kekerasan, karena dilihat dari sudut korban kekerasan tetap mereka rasakan baik disengaja maupun tidak.

f. Yang tampak dan yang tersebunyi. Kekerasan yang tampak adalah yang nyata dirasakan oleh objek, baik secara personal maupun struktural. Sedangkan kekerasan tersembunyi tidak kelihatan namun tetap bias dengan mudah meledak. Kekerasan tersembunyi terjadi jika situasi menjadi begitu tidak stabil sehingga tingkat realisasi aKtual manusia dapat menurun dengan begitu mudah. Situasi ini disebut sebagai keseimbangan yang goyah (unstable equilibrium). ${ }^{10}$

Dalam penjelasan secara teoritis terhadap kekerasan yang terjadi dalam hubungan dengan pasangan setidaknya ada 3 teori yang digunakan yaitu:

1) Teori intraindividual. Penjelasan ini sering disebut sebagai teori psikopatologi. Pendekatan intraindividual mencoba mencapai pemahaman tentang tindakan pelaku untuk mengalahkan pasangannya dan ciri-ciri psikologis korban yang mengalami penganiayaan. Peneliti dalam teori ini mengemukakan mengenai kondisi kejiwaan dari pelaku serta pengaruh penggunaan alcohol dan obat-obatan terlarang yang mempengaruhi kondisi kejiwaan pelaku.

2) Teori penjelasan sosiokultural (patriarki). Teori ini melakukan pendekatan dengan pandangan mengenai dominasi laki-laki dalam masyarakat. Kekerasan terhadap perempuan dipandangan sebagau hasil perlakuan dalam susunan masyarakat patriarki.

3) Teori Pendekatan Pembelajaran Sosial: perspektif ketidakberdayaan yang dipelajari. Pendekatan terakhir adalah dengan menganalisis ketidakberdayaan korban untuk tetap berada pada situasi kekerasan, yang juga merupakan bagian dari tradisi sosiokultural. Beberapa ahli mengemukakan pandangan bahwa seseorang yang tidak meninggalkan pasangannya yang telah melakukan kekerasan disebab karena ketergantungan ekonomi, adanya anak dalam hubungan mereka, kerangnya ketrampilan untuk bekerja sebagai hasil dari penempatan peran perempuan dalam sejarah masyarakat. Gagasan tentang ketidakberdayaan yang dipelajari berpusat pada tiga komponen yakni informasi yang dimiliki seseorang tentang apa yang akan terjadi, pengetahuan atau persepsi tentang apa yang akan terjadi dan perilaku orang terhadap kejadian yang terjadi. Beberapa orang percaya bahwa mereka tidak dapat mempengaruhi atau mengendalikan apa yang akan terjadi pada mereka. Karena persepsi ini meningkat dan tumbuh semakin besar, korban percaya bahwa dia tidak berdaya untuk mengubah lingkungannya.

Kekerasan tidak terjadi setiap saat, namun dapat membentuk suatu lingkaran kekerasan. Secara bertahap, kekerasan dibangun melalui perasaan bahwa mereka tidak berdaya dan tidak mampu mengubah keadaan. Walker melihat siklus ini terdiri dari tiga tahap yang berbeda: (1) fase pembangunan ketegangan, (2) fase pemukulan, dan (3) periode rekonsiliasi.

1) Fase pembangunan ketegangan mungkin disertai oleh serangan ringan. Selama periode ini, perempuan tersebut percaya bahwa dia bisa menangkis intimidasi suaminya.

2) Bagian kedua dari siklus adalah episode pemukulan yakni puncak dari frustrasi yang dialami pada tahap pertama. Pada titik ini, orang itu berada di luar kendali dan bertindak dalam kemarahan. Seperti Walker (1979: 55) menjelaskan bahwa pelaku melakukan serangan untuk mengajari pasangannya dan tidak bermaksud menimbulkan luka tertentu pada dirinya. Tindakan ini berhenti saat pelaku merasa telah mempelajari pelajarannya. Pada saat ini, bagaimanapun, korban umumnya telah dipukuli dengan sangat parah.

3) Tahap terakhir adalah periode rekonsiliasi. Di sini pelaku mengubah dirinya menjadi karakter yang sangat menyesal, lembut, dan penuh kasih. Permohonan untuk pengampunan dan janji akan masa depan yang lebih baik sering menimbulkan kemarahan dan ketakutan yang dialami korban 
di tangan pasangannya. Pemukul benar-benar percaya bahwa dia tidak akan pernah lagi menyakiti perempuan yang dicintainya; pelaku percaya bahwa ia bisa mengendalikan dirinya mulai sekarang. Tindakan tersebut menjadi suatu pelajaran bagi pelaku. Setelah melakukan kekerasan, pelaku justru menunjukkan penyesalannya dengan melakukan hal-hal yang romantis.

Dalam perspektif siklus-kekerasan menunjukkan bahwa periode ini juga akan berlalu dan membentuk rantai kekerasan. Perempuan akan terjebak dalam hubungan yang semakin dalam. Ia bahkan akan sulit meninggalkan pelaku karena ketakutan akan penurunan standar hidup ketika meninggalkan pasangannya, apalagi jika mereka memilik anak dalam hubungan tersebut. Ketergantungan tersebut akan menyebabkan mereka menerima kekerasan dalam periode yang lama. Orang tua yang mengalami konflik akan terkuras waktunya untuk masalahnya sendiri, akibatnya anak akan kehilangan pengawasan terhadap anak. Akibatnya anak mengalami perlakuan yang salah.

Kriminolog, Larry J. Siegel menyatakan "children who grew up in homes wracked by conflict, attended inadequate schools, or associated with deviant peers became exposed to forces that engendered crime." yang berada pada lingkungan keluarga yang penuh konflik, tanpa pendidikan dan pengawasan yang optimal dari sekolah atau berada pada lingkungan teman-teman yang berperilaku menyimpang bertendensi untuk menimbulkan kejahatan. Kondisi buruk dalam pengasuhan ini setidaknya dapat dihubungkan dengan model-model kekerasan terhadap anak dalam lingkungan keluarganya. Maidin Gultom ${ }^{12}$ menuliskan beberapa model kekerasan yakni sebagai berikut: a. Mental illness model, kekerasan pada anak disebabkan oleh penyakit kejiwaan dan kelainan saraf.

b. Psychodynamic model, terjadinya kekerasan disebabkan karena kurangnya mothering dimana seseorang tidak pernah dirawat dengan ibu yang baik dan kemudian ia tidak dapat menjadi ibu yang baik dikemudian hari.

c. Personality or character trait model, yakni kekerasan yang terjadi karena orang tua yang belum cukup dewasa, agresif, berperilaku buruk, frustasi dan memiliki karakter yang kurang baik.

d. Social learning model, kurangnya kemampuan sosial yang ditunjukkan dengan ketidakpuasan menjadi orang tua. Perilaku yang ditunjukkan antara lain dengan menuntut anak bersikap seperti orang dewasa dan memiliki perasaan terganggu dengan kehadiran anak.

e. Family structure model, menunjukkan dinamika antar keluarga yang mempunyai hubungan kausalitas dengan kekerasan.

f. Environmental stress model, yakni memandang bahwa anak sebagai suatu masalah dimensional. Kekerasan pada anak disebabkan karena kehidupan yang menekan seperti pendidikan rendah dan ketiadaan pekerjaan yang layak.

g. Social-Psychological model, kekerasan pada anak disebabkan karena frustasi dan stress. Kondisi ini dapat disebabkan karena konflik dalam rumah tangga, isolasi secara sosial dan lain-lain.

Pola pengasuhan terhadap anak yang diwarnai kekerasan akan menyebabkan anak terlatih untuk melakukan kekerasan, sehingga pelaku anak sesungguhnya adalah korban dari lingkungan sosialnya. Ian Marsh, John Cochrane and Gaynor Melville ${ }^{13}$ membagi kategori korban sebagai korban primer dan korban sekunder. Selanjutnya mereka menjelaskan sebagai berikut:

Primary victims are those who experience the act or its consequences at first hand, for instance a child who is the victim of a hit and run driver. Secondary victims are those who suffer the effects but are not immediately involved, for instance the relatives of that child. To define the victims of crime is not an easy task; and it would be helpful here to outline very briefly some of the major examples of victims of crime to highlight this difficulty. 
Korban dapat dikategorikan sebagai primer atau sekunder. Korban primer adalah mereka yang mengalami tindakan atau konsekuensinya secara langsung, misalnya anak yang menjadi korban pengendara motor dan lari. Korban sekunder adalah mereka yang menderita efek tapi tidak segera dilibatkan, misalnya kerabat anak itu. Untuk menentukan korban kejahatan bukanlah tugas yang mudah; dan akan sangat membantu saat ini untuk menjelaskan secara singkat beberapa contoh utama korban kejahatan untuk menyoroti kesulitan ini.

Anak sebagai korban mengalami penderitaan yang tidak hanya berlangsung singkat, namun dapat menjadi penderitaan yang berkepanjangan, karena karakter dari cyberbullying yang dilakukan secara berulangulang (repetition) oleh sebab itu perlindungan korban menjadi kajian penting dalam kebijakan hukum pidana.

\section{Kajian terhadap Chapter 10 Child Maltreatment}

Dalam bab mengenai child maltreatment ini, penulis menjabarkan penelitian di bidang perlakuan yang salah terhadap anak telah berkisar pada tiga pertanyaan. Pertama, seberapa luas atau lazimnya pelecehan dan pengabaian anak? Kedua, apa korelasi perlakuan yang salah terhadapanak? Ketiga, apa yang menyebabkan orang terlibat dalam jenis perilaku ini? Selain masalah ini, bab ini membahas apa yang dimaksud dengan pelecehan dan pengabaian anak, apa yang dilambangkan oleh undang-undang pelecehan anak, dan beberapa strategi yang disarankan orang untuk mengatasi masalah ini.

Penulis mulai mengkaji mengenai kasus perlakuan yang salah terhadap terhadap anak dari latar belakang budaya. Dalam sebagian besar sejarah, anak-anak dipandang sebagai milik keluarga. Orang Romawi kuno percaya bahwa sang ayah dianugerahi dengan kekuatan patriae potestas (Thomas, 1972). Dengan kata lain, ayah memiliki hak untuk menjual, membunuh, atau membiarkan keturunan mereka terus hidup. Orang-orang Yunani kuno, terutama orang-orang
Spartan, mempraktikkan pembunuhan bayi dan meninggalkan bayi baru lahir cacat (deMause, 1974). Kisah Oedipus Rex adalah kesaksian akan kenyataan bahwa praktik-praktik ini diterima di kalangan kelas yang lebih rendah dan lebih tinggi di masyarakat. Kisah-kisah alkitabiah juga menggambarkan kasus perlakuan yang salah terhadap anak, seperti pengorbanan Abraham atas anaknya Ishak dan pembantaian Herodes atas orang-orang yang tidak berdosa. Laporan lain tentang perlakuan tidak manusiawi terus berlanjut selama berabad-abad. Anak-anak diperlakukan tidak berbeda dengan barang lain yang dimiliki oleh ayah.

Fakta perlakuan yang salah terhadap anak juga dikaji dari anggapan bahwa kekerasan yang dilakukan tersebut berada pada ranah privasi dan tindakan tersebut menjadi otoritas dari orang tua. Apa yang terjadi di dalam rumah, tidak boleh dijangkau oleh masyarakat. Penelitian mengenai perlakuan yang salah terhadap anak ini dimulai sejak tahun 1946 oleh John Caffey, seorang ahli radiologi anak-anak, yang menguraikan kerusakan tulang asal misterius yang ia temukan di beberapa pasien anak. Meskipun tidak menuduh orang tua menjadi sumber langsung dari luka-luka ini, Caffey (1946) mencatat bahwa beberapa penjelasan orang tua tentang berbagai kecelakaan tidak masuk akal. Penemuan Caffey mendorong dokter lain untuk melakukan penyelidikan serupa. Para periset ini juga berhenti menyalahkan orang tua karena penderitaan yang disengaja dari luka yang diamati. Dalam publikasi yang inovatif, Tim riset radiologi Kempe (1962: 107) menerapkan terminologi baru ini kepada "anak-anak muda yang telah menerima penganiayaan fisik yang serius, umumnya dari orang tua atau orang tua asuh." Penemuan ini meluncurkan sebuah gerakan yang bertujuan untuk memberantas kekhawatiran yang baru ditemukan ini.

Hasil penelitian yang disusum oleh Tim Kompe terrsebut berimplikasi terhadap gerakan perlindungan hukum terhadap anak. Legislatif negara bagian berlomba untuk memberlakukan undang-undang baru. Bagian dari undang-undang federal yang menangai kekerasan dan pengabaian 
anak membawa standardisasi yang lebih besar ke undang-undang negara bagian. Kajian ilmiah dilakukan terhadap dua istilah yakni abuse dan neglect.Abuse adalah tindakan yang dilakukan terhadap anak, sementara neglectmengacu pada kelalaian fungsi pengurus. Definisi Hukum Sebagian besar undang-undang negara bagian mendefinisikan perlakuan salah dan pengabaian dengan istilah yang sangat umum. Tujuan di balik pendekatan ini adalah mendorong pelaporan sebanyak mungkin dugaan kasus. Perlakuan salah umumnya mengacu pada kemungkinan cedera nonaksidental yang secara serius merusak kesehatan fisik atau mental anak. Sebagian besar definisi undang-undang melarang pelecehan seksual, eksploitasi seksual, pornografi, dan pelacuran remaja. Beberapa yurisdiksi menjadikannya sebuah titik untuk mengecualikan tindakan disipliner yang wajar seperti pukulan anak yang dikendalikan oleh orang tua, wali, atau kustodian.

Tipe umum dari kekerasan dan kelalaian terhadap Anak dapat dibedakan menjadi berikut:

1) Kekerasan fisik adalah cedera fisik yang tidak berbahaya (mulai dari memar kecil hingga patah tulang atau kematian yang parah) akibat pukulan, pemukulan, menendang, menggigit, menggoyangkan, melempar, menikam, tersedak, memukul (dengan tangan, tongkat, tali, atau benda lain), membakar, atau merugikan anak, yang ditimbulkan oleh orang tua, pengasuh, atau orang lain yang memiliki tanggung jawab terhadap anak tersebut. Cedera tersebut dianggap penyalahgunaan terlepas dari apakah pengasuh tersebut bermaksud menyakiti anak tersebut. Disiplin fisik, seperti memukul pantat atau mengayuh, tidak dianggap sebagai penyalahgunaan asalkan masuk akal dan tidak menyebabkan luka fisik pada anak.

2) Kelalaian adalah kegagalan orang tua, wali, atau pengasuh lainnya untuk memenuhi kebutuhan dasar anak. Kelalaian dapat berupa:

- Fisik (misalnya, kegagalan untuk menyediakan makanan atau tempat tinggal yang diperlukan, atau kurangnya pengawasan yang tepat)
- Medis (mis., Tidak memberikan perawatan medis medis atau mental yang diperlukan)

- Pendidikan (misalnya, kegagalan mendidik anak atau menghadiri untuk kebutuhan pendidikan khusus)

- Emosional (misalnya, kurang memperhatikan kebutuhan emosional anak, kegagalan memberikan perawatan psikologis, atau mengizinkan anak tersebut menggunakan alkohol atau obat lain)

3) Kekerasan seksual mencakup tindakan yang dilakukan oleh orang tua atau pengasuh seperti membelai alat kelamin anak, penetrasi, inses, pemerkosaan, sodomi, paparan tidak senonoh, dan eksploitasi melalui prostitusi atau produksi bahan pornografi.

4) Kekerasan emosional (atau pelecehan psikologis) adalah pola perilaku yang mengganggu perkembangan emosional anak atau rasa harga diri. Ini mungkin termasuk kritik konstan, ancaman, atau penolakan, serta menahan cinta, dukungan, atau bimbingan. Kekerasan emosional seringkali sulit dibuktikan dan, oleh karena itu, layanan perlindungan anak mungkin tidak dapat diintervensi tanpa bukti adanya luka atau luka mental pada anak tersebut. Kekerasan emosional hampir selalu hadir saat bentuk lain diidentifikasi.

5) Pengabaian sekarang didefinisikan di banyak Negara sebagai bentuk pengabaian. Secara umum, seorang anak dianggap ditinggalkan saat identitas orang tua atau keberadaannya tidak diketahui, anak tersebut ditinggalkan sendirian dalam keadaan dimana anak tersebut menderita bahaya serius, atau orang tua telah gagal untuk menjaga kontak dengan anak tersebut atau memberikan dukungan yang masuk akal untuk jangka waktu tertentu.

6) Penyalahgunaan zat merupakan unsur definisi kekerasan atau pengabaian anak di banyak negara. Keadaan yang dianggap kekerasan atau pengabaian di beberapa negara meliputi Paparan pralahir anak yang disebabkan oleh penggunaan obat bius atau zat lain oleh ibu, Pembuatan methamphetamine di hadapan anak, menjual, mendistribusikan, atau memberi 
izin obat-obatan atau alkohol kepada anak dan penggunaan zat yang dikendalikan oleh pengasuh yang mengganggu kemampuan pengasuh untuk merawat anak secara memadai.

Tipe-tipe kekerasan terhadap anak ini menjadi isu kunci dalam mengidentifikasi bullying. Menurut psikolog Andrew Mellor ${ }^{14}$, ada beberapa jenis bullying, yakni:

a. Bullying fisik, yaitu jenis bullying yang dilakukan dengan kontak fisik antara pelaku dan korban. Perilaku ini lebih mudah diidentifikasi dibandingkan dengan bentuk lainnya.

b. Bullying verbal, yaitu bullying yang dilakukan dengan melibatkan bahasa verbal yang bertujuan menyakiti hati seseorang.

c. Bullying relasi sosial adalah bullying yang bertujuan menolak dan memutus relasi sosial korban dengan orang lain dengan mempermalukan korban, merusak reputasi seseorang, mengajak orang lain untuk menjauhi, meliputi pelemahan pribadi korban secara sistematis melalui pengabaian, pengucilan atau penghindaran

d. Bullying elektronik merupakan merupakan bentuk perilaku bullying yang dilakukan melalui alat komunikasi elektronik seperti komputer, telepon seluler internet, website, chatting room, e-mail, SMS, dan lain-lain. Tindakan ini disebut dengan cyberbullying.

Penjelasan untuk perlakuan yang salah terhadap anak dan interpretasi karakteristik terbagi dalam tiga pendekatan populer: (1) teori intraindividual, (2) penjelasan sosiokultural, dan(3) pendekatan pembelajaran sosial

a. Teori Intraindividu. Pendekatan intraindividual memandang penganiayaan anak sebagai produk dari cacat internal atau cacat di dalam pelaku. Seharusnya, defisiensi kepribadian ini menyebabkan "kurangnya penghambatan dalam mengekspresikan frustrasi dan perilaku impulsif lainnya"(Spinetta \& Rigler, 1972: 299). Jika peneliti dapat mengidentifikasi gangguan yang ada pada pelaku anak, maka langkah selanjutnya adalah mengembangkan rencana perawatan yang tepat. b. Teori penjelasan sosiokultural. Pendekatan sosiokultural mencari peristiwa yang bersifat eksternal bagi individu. Orientasi ini menekankan jumlah stres yang ditemukan di dalam keluarga. Faktor-faktornya seperti pengangguran, ukuran keluarga, jarak keluarga, dan isolasi sosial. Pendekatan sosiologis untuk menjelaskan perlakuan yang salah terhadap anak tidak luput dari kritik. Satu masalah adalah bahwa model tersebut gagal menjelaskan mengapa beberapa keluarga yang stres tidak beralih ke kekerasan anak sebagai jalan keluar. Model ini juga mengabaikan strategi penanggulangan yang ada.

c. TeoriPendekatan Pembelajaran Sosial. Teori belajar sosial berfokus pada penyerapan pengalaman dan penguatan. Tinjauan terhadap 29 studi empiris yang menganalisis anak-anak yang menyaksikan kekerasan orang tua memang menemukan kaitan dengan beberapa jenis masalah perkembangan (Kolbos, Blakely, \& Engleman, 1996). Ringkasan literatur yang lebih baru sependapat dan mencatat bahwa anak-anak yang menyaksikan kekerasan orang tua juga lebih cenderung menjadi korban perlakuan yang salah (Herrenkohl et al., 2008; Holt, Buckley, \& Whelan, 2008). Demikian pula, anak-anak yang mengalami perlakuan yang salah ini berisiko berpikir bahwa perilaku ini dapat diterima karena orang tua mereka mempraktikkannya. Ketika anak-anak ini tumbuh dan membentuk hubungan intim mereka sendiri, tindakan kekerasan yang sama mungkin muncul ke permukaan.

Kajian mengenai kasus-kasus kekerasan terhadap anak menimbulkan pertanyaan kembali apakah bahwa semua anak memiliki rumah yang aman dan suasana penuh cinta untuk tumbuh dan berkembang? Salah satu pilihan yang dilakukan negara bagian adalah mencabut hak asuh orang tua dan menempatkan anak di rumah asuh atau di perumahan alternatif lainnya. Prosedur seperti itu hanya akan terjadi dalam situasi yang paling ekstrem dan merupakan usaha terakhir. Beberapa tindakan lain yang dilakukan adalah dengan memberikan perawatan medis dan psikologis, 
penegakan hukum. Prosedur ini dapat pula dilakukan sebagai pemulihan terhadap anak yang menjadi korban cyberbullying. Ada beberapa pilihan yang dilakukan yakni:

1) Kunjungan rumah

Salah satu pilihan kebijakan sosial yang menarik perhatian adalah program kunjungan rumah dan program penyaringan kesehatan. Pendukung menyarankan agar petugas kesehatan masyarakat harus melakukan kunjungan rutin ke rumah di mana ada anak kecil dan bayi baru lahir (Leventhal, 2001; Mencegah Pelecehan Anak Amerika, 2003). Kunjungan rumah ini akan melayani tujuan ganda. Tujuan pertama adalah pencegahan. Pekerja dapat membantu orang tua baru untuk menyesuaikan diri dengan keturunan mereka dengan menunjukkan kepada mereka cara merawat bayi dan menghilangkan kekhawatiran menjadi orang tua. Tujuan kedua adalah mengungkap kasus perlakuan yang salah dan kondisi perkembangan buruk lainnya.

2) Pendidikan

Upaya pendidikan bertujuan untuk mengurangi kesulitan anak dengan memberi instruksi kepada orang tua dalam perkembangan anak. Beberapa pengamat berpendapat bahwa kurikulum sekolah menengah harus berisi kursus keluarga.

3) Hukum Safe Havenmerupakan upaya untuk menangani pengabaian bayi dan pembunuhan bayi. Orang tua mungkin ingin menyembunyikan kelahiran bayi dengan berbagai alasan, tidak berada dalam posisi untuk memikul tanggung jawab membesarkan anak itu, atau kekurangan sumber daya yang cukup untuk merawat bayi yang baru lahir. Di masa lalu, beberapa orang tua telah bereaksi dengan membiarkan bayi mereka yang baru lahir tanpa pengawasan dengan harapan seseorang akan menemukan bayi yang terlantar dan menyelamatkannya. Bayi telah ditemukan di toilet, tempat pembuangan sampah, pintu masuk, dan lokasi kurang optimal lainnya. Dalam beberapa kasus tragis, bayi-bayi ini lolos dari pemberitahuan, tidak terdeteksi, dan kemudian meninggal dunia.
4) Orang tua anonim

Orangtua anonim adalah organisasi nirlaba nasional dengan cabang-cabang lokal. Kelompok lokal terdiri dari orang tua yang merasa sedang melakukan perlakuan yang salah, atau dalam bahaya melakukan perlakuan yang salah, anak-anak mereka. Organisasi nasional mengoperasikan hotline 24 jam yang bisa dipanggil orang tua saat mereka perlu melampiaskan frustrasi atau kemarahan mereka.

\section{5) Konseling}

Jalan lain untuk menangani kasus perlakuan yang salah terhadap anak adalah dengan menekankan pada pendekatan pengobatan atau rehabilitasi. Respon ini berusaha membantu korban dan pelaku, yang sering melibatkan seluruh keluarga. Sebagian besar intervensi pengobatan berkisar pada konseling individu dan kelompok.

6) Pusat Advokasi Anak-anak

Pusat Advokasi Anak-anak (Children's Advocacy Center / $C A C$ ) adalah organisasi payung, terlepas dari sistem peradilan pidana, yang menyatukan pekerja layanan perlindungan anak, petugas penegak hukum, kantor kejaksaan, pendidik, konselor kesehatan mental, dan petugas medis dalam upaya memberikan respon terkoordinasi dan penyampaian layanan tanpa batas kepada anakanak yang telah diperlakukan dengan buruk. Pendekatan tim multidisiplin ini dirancang agar anak-anak tidak terbawa dari satu lembaga ke agen berikutnya dan menyediakan berbagai layanan di bawah satu atap. CAC pertama membuka pintunya pada tahun 1985 di Huntsville, Alabama. Sejak saat itu, konsep ini telah berkembang, dan sekarang ada lebih dari 700 CAC yang beroperasi di seluruh negeri (National Children's Alliance, 2010).

7) Pendaftaran dan Pemberitahuan Pelaku KekerasanSeksual

Pendaftaran dan pemberitahuan Pelaku KekerasanSeksual(SORN) berarti bahwa ketika terpidana pelaku dilepaskan dari kurungan, mereka harus memberi tahu pihak 
berwenang secara berkala mengenai tempat tinggal dan pekerjaan mereka.

8) Komitmen Masyarakat

Masalah dan kegagalan yang terkait dengan manajemen pelaku kekerasan seksual telah membawa pengakuan awal bahwa cara menangani pelaku saat ini terkadang tidak efektif. Banyak pelaku kekerasan seksual memiliki sejarah kriminal yang panjang, tidak dapat diobati dengan pengobatan, dan akan mengulangi kembali setelah dilepaskan. Akibatnya, beberapa negara bagian telah menerapkan prosedur untuk pelaku kekerasanseksualyang sakit mental dalam upaya mencegah korban di masa depan. Dengan kata lain, setelah pelaku kekerasanseksualberbahaya menyelesaikan hukuman penjara, negara akan memulai proses hukum untuk membatasi orang ini tanpa batas waktu di institusi mental.

9) Amber Alert

Pada bulan Januari 1996, seorang gadis berusia sembilan tahun, Amber Hagerman, mengayuh sepedanya di jalan. Sopir truk pick-up hitam menepi, meraih Amber, dan mendorongnya masuk ke dalam kendaraan. Dia kemudian melesat pergi. Saksi yang menyaksikan peristiwa tersebut memberitahukan polisi. Namun, penyelidikan tersebut tidak menghasilkan bukti atau petunjuk tambahan. Amber telah lenyap di siang hari. Mayatnya ditemukan empat hari kemudian. Amber telah dibunuh. Perlahan-lahan, kekhawatiran akan keamanan anak ini digarisbawahi kemudian harus dilakukan untuk memaparkan informasi mengenai media cetak (lihat Tabel 10-10). Sebagai tambahan, sebuah rencana yang dikembangkan di mana stasiun radio lokal dan saluran televisi akan menyiarkan informasi penting mengenai siapa pun yang melihat korban dan/atau petugas polisi dapat memberi tahu pihak berwenang. Perusahaan telepon seluler, penyedia layanan Internet, industri truk, dan pemilik billboard juga menjadi mitra. Saat ini, 50 negara bagian memiliki beberapa bentuk sistem Amber Alert.
10) Reformasi Hukum

Partisipasi dalam proses peradilan pidana bisa menjadi pengalaman traumatis bagi anak-anak. Sebenarnya, American Bar Association (1996) mewajibkan advokat untuk mempertimbangkan kesejahteraan anak secara hati-hati sebelum memutuskan apakah korban harus bersaksi di pengadilan. Namun, kesaksian korban merupakan komponen penting dalam sistem peradilan yang merugikan. Tanpa keterangan korban, kebanyakan kasus tidak mudah dituntut. Akibatnya, beberapa yurisdiksi mempekerjakan konselor korban untuk membantu menanggulangi pergolakan emosional yang dialami korban dan untuk mempertahankan kredibilitas korban dengan meningkatkan ingatan kognitif(Geiselman, Bornstein, \& Saywitz, 1992).

Prosedur terhadap pemulihan anak sebagaimana ditulis oleh penulis merupakan politik hukum untuk menanggulangi kejahatan terhadap anak. Politik hukum merupakan kebijakan yang dilakukan oleh negara melalui penetapan peraturan-peraturan yang dikehendaki dan juga diprediksi akan digunakan odan sesuai denga masyarakat. Kebijakan tersebut dilakukan melalui badan-badan negara. ${ }^{15}$

\section{Kajian terhadap Chapter 12 Victimization at Work and School}

Penulis memilih social setting yakni tempat kerja dan sekolah sebagai lokasi dimana seseorang banyak menghabiskan waktu. Interaksi yang terjadinya sangat memungkinkan terjadinya kejahatan. Penulis selanjutnya mengatakan bahwa kejahatan lebih mungkin terjadi ketika: (1) target yang sesuai, (2) pelaku yang termotivasi, dan (3) tidak adanya wali. Baik tempat kerja maupun sekolah biasanya membawa ketiga gagasan kunci ini bersama-sama. Kenyataan bahwa kebanyakan orang dewasa memiliki pekerjaan dan kebanyakan anak muda, secara hukum, harus bersekolah memenuhi syarat pertama. Fakta yang sama juga membahas kondisi kedua karena memiliki pelaku yang termotivasi. Pergi ke tempat kerja atau sekolah membawa berbagai individu pada suatu 
kelompok. Dari kelompok individu inilah pelaku dan korban potensial muncul. Faktor ketiga, kurangnya wali, mungkin merupakan bagian yang tidak menguntungkan dari banyak sekolah dan tempat kerja. Sekolah dan pengusaha mungkin tidak fokus atau siap memberikan perlindungan kepada pihak-pihak yang sering melakukan lokasi mereka. Kebutuhan untuk mengambil tindakan perlindungan mungkin tidak muncul di masa lalu. Media, peneliti, dan berbagai lembaga telah memberikan perhatian yang meningkat terhadap optimisasi di tempat kerja dan sekolah, terutama dalam hal terjadinya kekerasan dalam beberapa tahun terakhir. Ilustrasi terbaik dari fokus ini dapat ditemukan dalam perhatian yang diberikan pada masalah di media. Penembakan di tempat kerja dan di sekolah merupakan berita utama, dan liputan sering berlanjut di televisi selama bermingguminggu atau berbulan-bulan setelah kejadian tersebut.

Pembahasan dalam Chapter 12 ini sangat menarik karena membahas mengenai viktimisasi bullying di dunia pendidikan. Tindakan bullying sesungguhnya bukan merupakan hal baru dalam suatu relasi sosial. Rajitha Kota, Shari Schoohs, Meghan Benson and Megan A. Moreno ${ }^{16}$, mengatakan "Bullying occurs throughout the world and can happen at many stages in the life course-from childhood, to adolescence, even to adulthood. Though traditional "schoolyard" bullying still exists, in recent years the Internet has provided a new platform for bullying. "Bullying terjadi di seluruh dunia dan bisa terjadi pada banyak tahap dalam kehidupan - dari masa kanak-kanak, hingga masa remaja, bahkan sampai dewasa. Meskipun bullying tradisional yang biasanya dilakukan di sekolah masih ada, dalam beberapa tahun terakhir, Internet telah menyediakan platform baru untuk melakukan intimidasi.

Dalam buku ini, penulis memaparkan bahwa menurut NCVS 2007: Suplemen Kejahatan Sekolah, sekitar sepertiga dari semua siswa dilaporkan diintimidasi di sekolah (Dinkes et al., 2009). Bullying dibagi secara merata ke seluruh jenis kelamin, ras (kecuali orang Asia, yang paling sedikit diintimidasi), dan sekolah negeri/ swasta. Perilaku bullying menurun dengan tingkat kelas. Siswa bukan satu-satunya korban potensial di sekolah. Guru, administrator, dan staf lainnya juga bisa menjadi target. Data dari survei guru menunjukkan bahwa sejumlah besar telah menjadi korban kekerasan atau ancaman kekerasan di sekolah. Menurut Pusat Statistik Pendidikan Nasional, lebih dari 440.000 guru diserang secara fisik atau diancam oleh seorang siswa selama tahun ajaran 2007-2008 (Dinkes et al., 2009). Ini mewakili sekitar 10\% dari semua guru.

Respon siswa terhadap kekerasan yang terjadi disekolah menunjukkan dampak sebagai berikut:

a. Perilaku penghindaran. Suplemen Kejahatan Sekolah melaporkan bahwa 7,2\% siswa menghindari sekolah, kegiatan sekolah, dan/ atau tempat tertentu di sekolah karena takut diserang atau diserang (Dinkes et al., 2009).

b. Siswa mungkin bersekolah, namun kualitas pendidikan yang mereka terima berkurang. Beberapa siswa mungkin kelaparan, menderita ketidaknyamanan karena mereka takut menggunakan toilet, terlambat masuk kelas karena hanya menggunakan tangga atau lorong tertentu, atau menahan diri untuk tidak mengikuti aktivitas ekstrakurikuler.

c. Tindakan pembelaan diri, terutama membawa senjata untuk perlindungan. Menurut data Survei Perilaku Resiko Pemuda yang dilakukan oleh Centers for Disease Control and Prevention, 6\% siswa SMA melaporkan membawa senjata ke sekolah setidaknya satu kali dalam 30 hari terakhir (Dinkes et al., 2009). Lab dan Clark (1996) menemukan bahwa 24\% responden membawa senjata ke sekolah untuk perlindungan setidaknya sekali dalam jangka waktu enam bulan. Bahkan tingkat kepemilikan senjata yang lebih tinggi di sekolah muncul dalam studi tentang sekolah di dalam kota (lihat, misalnya, Sheley, McGee, \& Wright, 1995). Di antara senjata yang dibawa untuk perlindungan adalah senjata, pisau, buku jari kuningan, pisau cukur, perhiasan berduri, dan gada (Lab \& Clark, 1996). 
Pembiaran adalah respon yang cukup lazim dari anak ketika menghadapi bullying. Lingkungan sekitar juga seringkali memberikan respon yang sama terhadap perilaku intimidasi tersebut. Pembiaran terhadap korban dilakukan karena beberapa alasan yakni:

a. Ketidakmampuan masyarakat untuk bereaksi terhadap penyimpangan yang terjadi.

b. Adanya ketakutan dari badan kontrol sosial atau korban penyimpangan akan kemungkinan adanya akibat yang bertentangan.

c. Ketidakpedulian/ pembiaran ini merupakan suatu iklim sosial yang ditimbulkan oleh tidak adanya reaksi yang luas terhadap tingkah laku yang tidak sesuai. ${ }^{17}$

Bullying yang terjadi di sekolah diselesaikan dengan berbagai program. Salah satu keuntungan dari intervensi ini adalah bahwa mereka berusaha untuk mengatasi kebutuhan korban dan pelaku kejahatan. Korban adalah peserta aktif dalam menanggapi setiap tindakan terhadap mereka dan dapat meminta ganti rugi atas kerugian atau cedera, sementara pelaku dapat mempelajari metode yang tepat untuk menangani perilaku dan dorongan anti sosialnya.

\section{Penutup}

Penemuan definisi dan bangunan teori mengenai cyberbulling sampai saat ini belum mencapai tingkat kemapanan. Hal ini dapat dipahami mengingat cyberbulling merupakan isu baru dalam bidang hukum. Berdasarkan pemahaman demikian, maka kajian terhadap cyberbullying dapat dilakukan dengan berbagai perspektif yakni dalam perspektif viktimologi dan kriminologi. Lorraine Wolhuter, Neil Olley dan David Denham dalam Chapter 2 membahas mengenai Theories of Victimologyyang dapat membantuk analisis mengenai cyberbullying. Teori viktimologi yang relevan dengan isu cyberbullying adalah viktimologi kritis, meskipun ada pandangan Mawby dan Walklate yang kurang relevan dengan analisis terhadap cyberbullying.

Pembahasan mengenai cyberbullying juga dipahami dari analisis mengenai Intimate Partner Violenceyang dibahas pada chapter 9
Victimology Sixth Editionkarya William G. Doerner Steven P. Lab. Kekerasan yang terjadi dalam hubungan antara pasangan ini akan melahirkan rantai kekerasan yang juga akan membentuk perlakuan yang salah terhadap anak sebagaimana yang dibahas dalam chapter 10 . Pelaku cyberbullying adalah orang yang pernah mengalami kekerasan, memendam kemarahan dan hidup penuh kekerasan. William G. Doerner Steven P. Lab. juga membahas mengenai bullying yang dilakukan pada masa sekolah.

\section{DAFTAR PUSTAKA}

Bernard L. Tanya, Yoan N. Simanjuntak dan Markus Y. Hage, 2010, Teori Hukum Strategi Tertib Manusia Lintas Ruang dan Generasi, Genta Publishing, Yogyakarta.

Doerner, William G. dan Lab, Steven P. 2012, Victimology Sixth Edition, Elsevier, Burlington.

Guckin, Conor Mc, and Corcoran, Lucie (eds), 2017, Cyberbullying: Where Are We Now? A Cross-National Understanding, MDPI, Basel.

Maidin Gultom, 2014, Perlindungan Hukum Terhadap Anak dan Perempuan, Refika Aditama, Bandung.

Marsh, Ian, John Cochrane and Gaynor Melville, 2004, Criminal Justice: An Introduction to Philosophies, Theories and Practice, Routledge, London

Muladi dan Diah Sulistyani R.S., 2016, Kompleksitas Perkembangan Tindak Pidana dan Kebijakan Kriminal, Alumni, Bandung.

Nashriana, 2012, Perlindungan Hukum Pidana Bagi Anak di Indonesia, RajaGrafindo Persada, Jakarta.

Rena Yulia, 2010, Viktimologi Perlindungan Hukum Terhadap Korban Kejahatan, Graha Ilmu, Yogyakarta.

Sage Knowledge, 2015, Critical Victimology: International Perspectives Perspectives on Victimology, Sage Publications, London. 
Siegel, Larry J., 2011, Fourth Edition Criminology The Core, Wadsworth, Belmont.

Siswanto Sunarso, 2012, Viktimologi dalam Sistem Peradilan Pidana, Sinar Grafika, Jakarta.

Wolhuter, Lorraine; Olley, Neil and Denham, David, 2009, Victimology : Victimisation and Victims'Rights, Routledge-Cavendish, New York.

Dicola, Daniel dan Elizabeth Spaar, "Intimate Partner Violence", American Family Physician, 2016-10-15, Volume 94, Issue 8.

Dorothy Wunmi Grigg, "Cyber-Aggression: Definition and Concept of Cyberbullying," Journal of Psychologists and Counsellors in Schools, Volume 20, Issue 2, December 2010.

Davit Setyawan, "KPAI : Kasus Bullying dan Pendidikan Karakter", Jakarta, http:// www.kpai.go.id/berita/kpai-kasus-bullyingdan-pendidikan-karakter/, diakses pada 19 September 2017.

Sameer Hinduja dan Justin W. Patchin, "Cyberbullying Legislation and Case Law Implications for School Policy and Practice", https://cyberbullying.org/cyberbullyinglegal-issues.pdf, diakses pada 16 Februari 2018.

Singapore Children's Society, "Profile of Cyber Bullie"s, Singapura, http:// bullyfree.sg/adults/adults-contact-us/, diakses pada 1 Oktober 2017.

\section{(Footnotes)}

1 Sameer Hinduja dan Justin W. Patchin, "Cyberbullying Legislation and Case Law Implications for School Policy and Practice", https://cyberbullying.org/cyberbullying-legalissues.pdf, diakses pada 16 Februari 2018.

${ }^{2}$ Singapore Children's Society, 'Profile of Cyber Bullie"s, Singapura, http://bullyfree.sg/ adults/adults-contact-us/, diakses pada 1 Oktober 2017.

${ }^{3}$ Nashriana, 2012, Perlindungan Hukum Pidana Bagi Anak di Indonesia, RajaGrafindo Persada, Jakarta, h. 40.
${ }^{4}$ Daniel Dicola dan Elizabeth Spaar, "Intimate Partner Violence", American Family Physician,201610-15, Volume 94, Issue 8, Pages 646-651.

${ }^{5}$ Sage Knowledge, 2015, "Critical Victimology: International Perspectives Perspectives on Victimology", Sage Publications, London, h. 15.

${ }^{6}$ Lorraine Wolhuter, Neil Olley and David Denham, 2009, Victimology : Victimisation and Victims' Rights, Routledge-Cavendish, New York, p. 28.

${ }^{7}$ Dorothy Wunmi Grigg, "Cyber-Aggression: Definition and Concept of Cyberbullying,"Journal of Psychologists and Counsellors in Schools, Volume 20,Issue 2, December 2010, pp. 143-156, h. 152.

${ }^{8}$ Larry J. Siegel, 2011, Fourth Edition Criminology The Core, Wadsworth, Belmont, h. 154.

${ }^{9}$ Bernard L. Tanya, Yoan N. Simanjuntak dan Markus Y. Hage, 2010, Teori Hukum Strategi Tertib Manusia Lintas Ruang dan Generasi, Genta Publishing, Yogyakarta, h. 182-183.

${ }^{10}$ Rena Yulia, 2010, Viktimologi Perlindungan Hukum Terhadap Korban Kejahatan, Graha Ilmu, Yogyakarta, h. 6-7.

${ }^{11}$ Larry J. Siegel, op.cit.t, h. 12.

12 Maidin Gultom, 2014, Perlindungan Hukum Terhadap Anak dan Perempuan, Refika Aditama, Bandung, h. 96-97.

${ }^{13}$ Ian Marsh, John Cochrane and Gaynor Melville, 2004, Criminal Justice: An Introduction to Philosophies, Theories and Practice, Routledge, London, h. 96.

${ }^{14}$ Davit Setyawan, "KPAI : Kasus Bullying dan Pendidikan Karakter", Jakarta,http:// www.kpai.go.id/berita/kpai-kasus-bullyingdan-pendidikan-karakter/, diakses pada 19 September 2017.

15 Muladi dan Diah Sulistyani R.S., 2016, Kompleksitas Perkembangan Tindak Pidana dan Kebijakan Kriminal, Alumni, Bandung, h. 79

${ }^{16}$ Rajitha Kota, Shari Schoohs, Meghan Benson and Megan A. Moreno, Characterizing "Cyberbullying among College Students: Hacking, Dirty Laundry, and Mocking", dalam Conor Mc Guckin, and Corcoran, Lucie (eds), 2017, Cyberbullying: Where Are We Now? A Cross-National Understanding, MDPI, Basel, h. 56 .

${ }^{17}$ Siswanto Sunarso, 2012, Viktimologi dalam Sistem Peradilan Pidana, Sinar Grafika, Jakarta, h. 65. 